\title{
Occurrence of syntopic species of shrews (Mammalia, Eulipotyphla) in a montane cloud forest of Mexico
}

\author{
Lázaro Guevara \\ Departamento de Zoología, Instituto de Biología, Universidad Nacional Autónoma de México, Apartado Postal 70-153, \\ 04510 México, Distrito Federal, México. 1lg@st.ib.unam.mx
}

Department of Biology, City College of New York, City University of New York, 526 Marshak Science Building, 160 Convent Avenue, 10031, New York, NY.

Fernando A. Cervantes

Departamento de Zoología, Instituto de Biología, Universidad Nacional Autónoma de México, Apartado Postal 70-153, 04510 México, Distrito Federal, México

Species-rich assemblages of shrews (Eulipotyphla, Soricidae) are typically associated with moist and cold habitats characterized by abundant food supplies (Kirkland, 1991). Indeed, nearly $40 \%$ of the Mexican shrew species are almost exclusively found in tropical montane cloud forests (González-Ruiz et al., 2014; Guevara et al., 2015), which are tightly linked to mist and high precipitation (Luna-Vega \& Magallón, 2010). Common soricids from this vegetation type include smalleared shrews (Cryptotis goldmani, C. goodwini, C. griseoventris, C. magnus, C. mexicanus, C. nelsoni, C. obscurus, C. peregrina, and C. phillipsii) and long-tailed shrews (Sorex ixtlanensis, S. macrodon, S. salvini, S. sclateri, S. stizodon, and S. veraepacis). However, data on coexistence of cloud forests species are still scarce (Woodman et al., 2012). This basic information is crucial for investigating interspecific competition and differentiation in foraging mode among coexisting taxa (Churchfield \& Rychlik, 2006).

As part of a short-term survey for collecting shrews during October 2006, our fieldwork team recorded the coexistence of

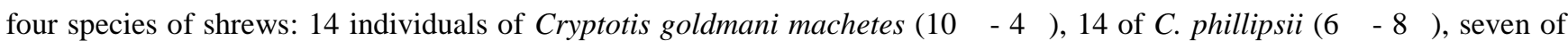
Sorex salvini oaxacae (7\%), and three of $S$. veraepacis mutabilis $\left(29-10^{7}\right)$. All these four taxa are not sister species, even when some of them are congeneric (Woodman \& Timm, 2000; Esteva et al., 2010; Guevara \& Cervantes, 2014). The collection site is a well-known locality for mammals, namely "Campamento Rio Molino" (16004' 46,74" N; 96028' 26,52" W, 2200-2280 m asl), in the municipality of San Miguel Suchixtepec, Oaxaca, southern Mexico (Musser, 1964; Schaldach, 1966). This place is surrounded by pine forest and by an exuberant cloud forest with a dense understory of ferns, mosses, and herbaceous vegetation. Our sampling effort consisted of two nights using 400 pitfall traps and 160 Sherman traps, located near to the stream courses through a canyon $\left(0.5 \mathrm{~km}^{2}\right)$. We used a collecting permission (FAUT-0002) issued by the Mexican government to catch mammals. Skins, skeletons, and tissues samples were deposited in the mammal collection of the Instituto de Biología, Universidad Nacional Autónoma de México (CNMA; Appendix 1).

After consulting literature and museum specimens of soricids previously collected around our collection site, we found one additional record identified as Sorex ixtlanensis captured near Rio Molino (University of Michigan Museum of Zoology, UMMZ 112574; Carraway, 2007). Two additional specimens from Rio Molino of Sorex lacking complete skeletons and consequently relevant variables in the discrimination of species remain with an uncertain identification (CNMA 8442-8443; Carraway, 2007). Other soricid documented in the municipality of San Miguel Suchixtepec is C. parvus pueblensis, which was taken in syntopy with C. phillipsii by Thomas B. MacDougall (AMNH 214809; Woodman \& Timm, 2000); as far as we know, there is no specific location of this occurrence record and we cannot corroborate if $C$. parvus pueblensis coexists with other species at Campamento Rio Molino.

To evaluate the morphological differentiation among coexisting species, we compared qualitative characters and four quantitative variables that are useful to tell closely related species apart (Woodman \& Timm, 2000; Carraway, 2007; Woodman \& Gaffney, 2014), based on all the specimens collected by us: weight (g), condylobasal length of skull, distal width

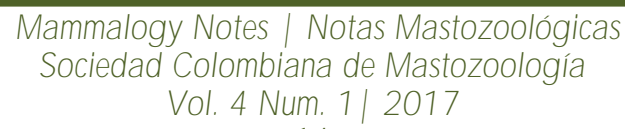


of humerus, and length of humerus $(\mathrm{mm})$. Measurements were taken with a Mitutoyo electronic calibrator at $0,1 \mathrm{~mm}$ precision under a stereomicroscope and descriptive statistics were displayed using scatter plots (Figure 1).

○. goldmani machetes - C. phillipsii

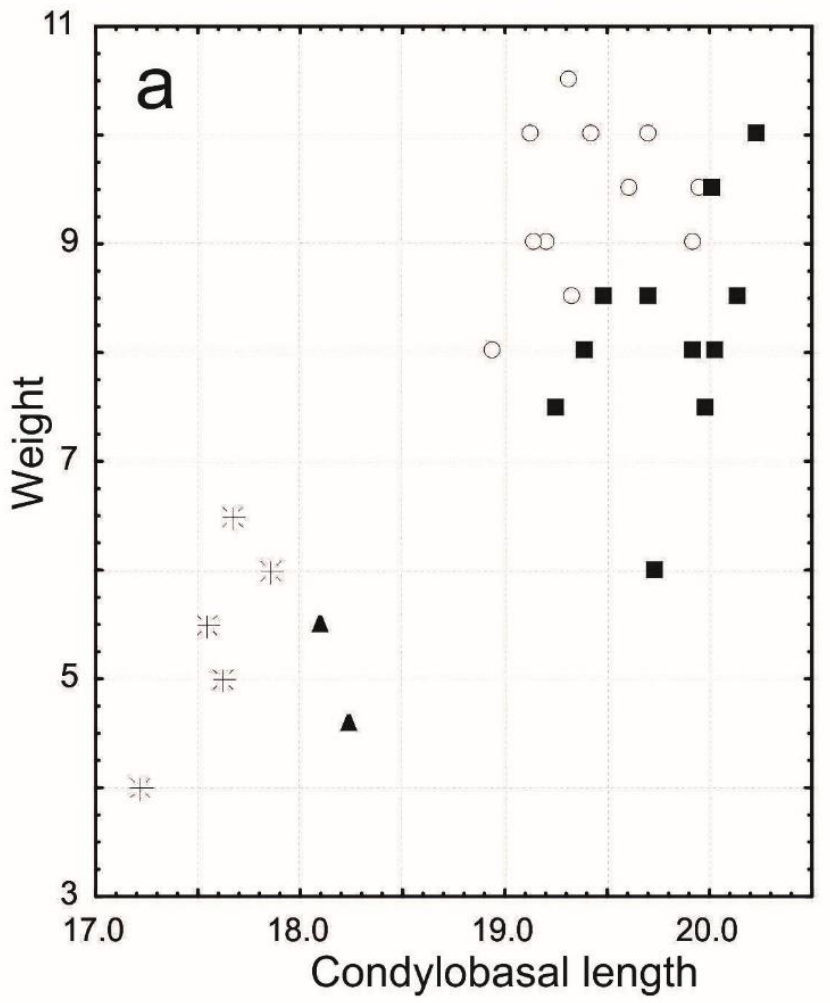

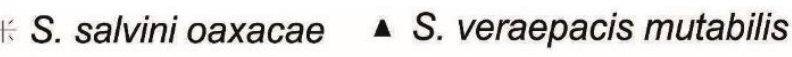

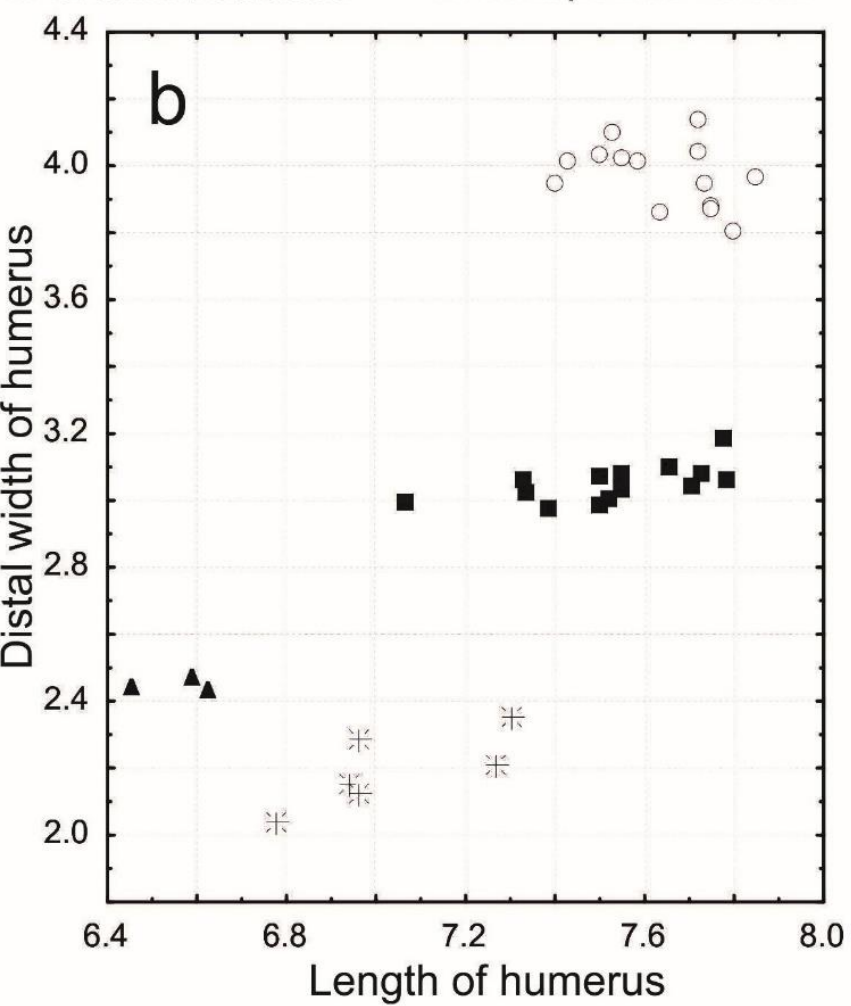

Figure 1. Scatter plots of quantitative variables for four species of shrews (Cryptotis and Sorex) coexisting in a cloud forest from Mexico. a) Weight (g) relative to condylobasal length; b) distal width of humerus relative to length of humerus (mm).

Firstly, there are distinctive external characteristics that tell apart Sorex from Cryptotis (Figure 1a). Species of Cryptotis have a large body with relatively short tail, forefeet enlarged, and foreclaws elongated. These attributes are typical of semi-fossorial or fossorial species of mammals, such as moles and some other genera of shrews (Hutterer, 1985; Woodman \& Morgan, 2005). Secondly, internal characters and quantitative analyses revealed that coexisting shrews consist of taxa of different body size and anatomical features. The two species of Cryptotis, C. goldmani machetes and C. phillipsi, are easily distinguishable on the basis of a suite of characters including the skull, teeth, postcranial skeleton and size (Figure 1a; Woodman \& Timm, 2000; Woodman \& Gaffney, 2014). Differences between the forefeet and foreclaws within the genus Sorex are less-obvious; despite this, it is easy to distinguish S. salvini oaxacae from S. veraepacis mutabilis based on the measurements of the humerus (Figure 1b). The lower incisor morphology (i1) also discriminates these species; the former has shallow interdenticular spaces on i1 with two denticles, while the latter has only deep interdenticular spaces on i1 with three conspicuos denticles (Carraway, 2007).

How differences in body size, tooth features, and humerus morphology among the four species allow habitat segregation at microhabitat scale remains to be tested under field studies of niche partitioning. For instance, the larger species of shrews may spend more time in underground tunnels than the smaller species that search for earthworms or hypogeal insects, reflecting foraging mode (Hanski, 1992; Rychlik, 2000). It has also been suggested that larger species are often more abundant than the smaller forms in more productive microhabitats (Hanski, 1992). Because our short-term fieldwork does not provide basis to support this hypothesis we strongly encourage a specific sampling design in order to better understand the role of body size in this shrew community assemblage (Brannon, 2000).

\section{Mammalogy Notes | Notas Mastozoológicas \\ Sociedad Colombiana de Mastozoología \\ Vol. 4 Num. 1| 2017}


Most likely shrews are very important components of Mexican cloud forests through the consumption of earthworms, insects, and other small vertebrates. Our recent field work and historical specimens from natural history museums indicate that this particular region in the State of Oaxaca withstands a high diversity of shrews with different evolutionary histories (Esteva et al., 2010; Guevara \& Cervantes, 2014; Guevara et al., 2015) and distinct morphologies (Woodman \& Timm, 2000). Previous field surveys in other fragments of cloud forest are also evidence of potentially syntopic shrew species in Mexico (Table 1; Sánchez-Cordero \& Guevara, 2016), Guatemala and Honduras (Woodman et al., 2012). Our findings should be considered just a first step in the process of obtaining a better understanding into the interspecific competition and coexistence of shrews in cloud forests.

Table 1. Cloud forest localities in Mexico with more than three coexisting species of shrews (Sánchez-Cordero \& Guevara, 2016)

\begin{tabular}{lll}
\hline Locality, Municipality & \multicolumn{1}{c}{ State } & \multicolumn{1}{c}{ Species } \\
\hline Around Omiltemi, & & $\begin{array}{l}\text { Cryptotis goldmani } \\
\text { Sorex ixtlanensis } \\
\text { Chilpancingo de los Bravo }\end{array}$ \\
& Guerrero & $\begin{array}{l}\text { Salvini } \\
\text { S. veraepacis. }\end{array}$ \\
\hline Around Vista Hermosa, & & $\begin{array}{l}\text { Cryptotis magnus } \\
\text { C. mexicanus }\end{array}$ \\
Santiago Comaltepec & Oaxaca & $\begin{array}{l}\text { C. goldmani } \\
\text { Sorex salvini. }\end{array}$ \\
\hline From 2 to 4,5 km S of Vista Hermosa (by road), & Oaxaca & $\begin{array}{l}\text { Cryptotis magnus } \\
\text { Sorex macrodon }\end{array}$ \\
& & S. salvini \\
Santiago Comaltepec & & S. veraepacis. \\
\hline
\end{tabular}

\section{Acknowledgments}

We thank J. Vargas, J. Arcangeli, L. Reyes, K. Ramos, and L. Juarez for providing help during field work. We thank the editor and two anonymous reviewers for their constructive comments. We dedicate this contribution to people from San Miguel Suchixtepec, Oaxaca, who provided exceptional help in the field.

\section{References}

BRANNON, M. P. 2000. Niche relationships of two syntopic species of shrews, Sorex fumeus and S. cinereus, in the Southern Appalachian Mountains. Journal of Mammalogy 81:1053-1061.

CARRAWAY, L. 2007. Shrews (Eulypotyphla: Soricidae) of Mexico. Monographs of the Western North American Naturalist 3:1-91.

CHURCHFIELD, S. \& L. RYCHLIK. 2006. Diets and coexistence in Neomys and Sorex shrews in Białowieża forest, eastern Poland. Journal of Zoology 269:381-390.

ESTEVA, M., et al. 2010. Molecular phylogeny of long-tailed shrews (genus Sorex) from México and Guatemala. Zootaxa 2615:47-65.

GONZÁLEZ-RUIZ, N., et al. 2014. Mamíferos del bosque mesófilo de montaña en México. Pp. 305-326, in Bosques mesófilos de montaña de México: diversidad, ecología y manejo (Gual-Díaz, M and A Rendón-Correa, comps.), Comisión Nacional para el Conocimiento y Uso de la Biodiversidad. México.

GUEVARA, L. \& F. A. CERVANTES. 2014. Molecular systematics of small-eared shrews (Soricomorpha, Mammalia) within Cryptotis mexicanus species group from Mesoamerica. Acta Theriologica 59:233-242.

GUEVARA. L., et al. 2015. Riqueza, distribución y conservación de los topos y las musarañas (Mammalia, Eulipotyphla) de México. Therya 6:43-68.

HANSKI, I. 1992. Insectivorous mammals. Pp. 163-187, in Natural enemies: the population biology of predators, parasites and diseases. (Crawley MJ, ed.), Blackwell Scientific Press, Oxford, UK.

HUTTERER R. 1985. Anatomical adaptations of shrews. Mammal Review 15:43-55.

KIRKLAND Jr., G. L. 1991. Competition and coexistence in shrews (Insectivora: Soricidae). Pp. 15-22, in: The biology of the Soricidae (Findley JS and TL Yates, eds.), Special Publication of the Museum of Southwestern Biology, University of New Mexico, Albuquerque.

LUNA-VEGA, I. \& S. MAGALLÓN. 2010. Phylogenetic composition of angiosperm diversity in the cloud forests of Mexico. Biotropica 42:444-454.

MUSSER, G. G. 1964. Notes on geographic distribution, habitat, and taxonomy of some Mexican mammals. Occasional Papers of the Museum of Zoology, University of Michigan 636:1-22.

RYCHLIK, L. 2000. Habitat preferences of four sympatric species of shrews. Acta Theriologica 45:173-190.

SÁNCHEZ-CORDERO, V. \& L. GUEVARA. 2016. Modelado de la distribución potencial de las musarañas (Mammalia, Soricidae). Universidad Nacional Autónoma de México. Instituto de Biología. Bases de datos SNIB-CONABIO, proyecto No. JM044. México, D.F.

\section{Mammalogy Notes | Notas Mastozoológicas \\ Sociedad Colombiana de Mastozoología \\ Vol. 4 Num. 1| 2017}


SCHALDACH, Jr., W. J. 1966. New forms of mammals from Southern Oaxaca, Mexico, with notes on some mammals of the coastal range. Saugetierkundliche Mitteilungen 4:286-297.

WOODMAN, N. \& R. M. TIMM. 2000. Taxonomy and evolutionary relationships of Phillips' small-eared shrew, Cryptotis phillipsii (Schaldach, 1966), from Oaxaca, Mexico (Mammalia: Insectivora: Soricidae). Proceedings of the Biological Society of Washington 113:339-355.

WOODMAN, N. \& J.J.P. MORGAN. 2005. Skeletal morphology of the forefoot in shrews (Mammalia: Soricidae) of the genus Cryptotis, as revealed by digital X-rays. Journal of Morphology 266:60-73.

WOODMAN, N, \& S. A. GAFFNEY. 2014. Can they dig it? Functional morphology and semifossoriality among small-eared shrews, genus Cryptotis (Mammalia, Soricidae). Journal of Morphology 275:745-759.

WOODMAN, N., et al. 2012. Distributional records of shrews (Mammalia, Soricomorpha, Soricidae) from Northern Central America with the first record of Sorex from Honduras. Annals of Carnegie Museum 80:207-237.

\section{Appendix I}

Specimens collected and examined: Cryptotis goldmani machetes (14).- CNMA 44675-44681, 44683-44689; C. phillipsii (14).- CNMA 44682, 44724- 44736; Sorex salvini oaxacae (7).- CNMA 44737-44742, 44746; S. veraepacis mutabilis (3).- 44743-44745. Additional specimens reported around the collection site (American Museum of Natural History, AMNH; California Academy of Science, CAS; Natural History Museum, University of Kansas, KU and Museum of Zoology, University of Michigan, UMMZ): C. goldmani machetes (3).- AMNH 214153; KU 124278, 124301; C. parvus pueblensis (1).- AMNH 214809; C. phillipsii (7).- AMNH 214152, 214803-214805; CAS 14068; KU 121661, 124298-124299; UMMZ 112572; Sorex ixtlanensis (1).- UMMZ 112574; S. salvini oaxacae (3).- AMNH 214801214802; CAS 14066-14067; KU 124310; UMMZ 112576-112577; Sorex sp. (2).- CNMA 8442-8443. 